\title{
Preliminary Overview on Thermal Performance of Green Roof
}

\section{Hartini Kasmin ${ }^{1, a}$, Nor Azizi Yusoff ${ }^{1, b}$, Muhammad Hasnolhadi Samsudin ${ }^{1, c}$, Norbaasithu Atan ${ }^{1, d}$, Rosniza Kassim², e, Hanim Ahmad ${ }^{2, f}$, Zulhazmi Sayuti², g, Firdaurs Abdullah ${ }^{1, \mathrm{~h}}$}

${ }^{1}$ Faculty of Civil and Environmental Engineering, Universiti Tun Hussein Onn Malaysia, Johor

${ }^{2}$ Horticulture Research Centre, MARDI Headquaters,

P.O. Box 12301, 50774 Kuala Lumpur

ahartini@uthm.edu.my, bazizy@uthm.edu.my, 'df100001@siswa.uthm.edu.my,

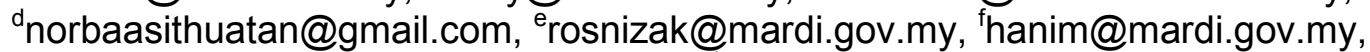

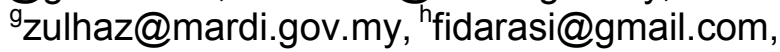

Keywords: Green roof, green building, thermal performance.

\begin{abstract}
Green roof has shown potential contribution on improving the functional performance of buildings by lowering the roof exterior surface temperature, which is indirectly, could potentially reduce the energy demand. In addition, it is likely to provide important ecological services to urban areas through lowering of urban heat island (UHI) temperatures, increasing storm water retention and improves the biodiversity. This paper will then present the initial outcomes of the joint initiative between Malaysia Agricultural Research and Development (MARDI) and Universiti Tun Hussein Onn Malaysia (UTHM) in promoting this green technology in Malaysia. As green roof technology is still emerging, there is limited technical data available at present in Malaysian climate. The study aims to provide initial observation on the thermal performance of green roof and its effect towards surrounding and associated significant environmental benefit. In order to achieve the goal, the thermal performance of green roof system in experimental plot at MARDI had been monitored. The green roof experimental plot has been set up on two flat roofs in Horticulture Research Centre, MARDI, Serdang, Selangor and the treatments consists of two green roof system known as conventional system and self-watering system. The substrate depths were $50 \mathrm{~mm}$ and $100 \mathrm{~mm}$. In addition, some observation on the attracted wildlife to the green roof was initiated. Based on the initial results, it is interesting to report that the temperature reduction for the green roofs on Roof 1 and Roof 2 were in averages of $6.1^{\circ} \mathrm{C}$ and $10^{\circ} \mathrm{C}$, respectively. In conclusion, this joint study between UTHM and MARDI may facilitate the development of roof top gardening system in greening the urban area. With more studies, it will possibly highlight the engineering significance, furthermore promoting the application of green roof technology in Malaysia.
\end{abstract}

\section{Introduction}

Nowadays with the growing concern over climate change, there has been increasing interest in using green roof as one of a sustainable strategy for the urban environment construction. Green roof may protect buildings from the effects of the natural elements [1]. Not only introducing more gardens in urban areas, green roof can even be used to promote urban farmings [2]. In addition, the roof garden could acts as a bio filter, enhancing air quality by breaking down harmful airborne contaminants and transforming them into clean oxygen [3]. It absorbs carbon dioxide and releases oxygen and therefore reduces greenhouse gases in the atmosphere. Furthermore, the technology could potentially improve the urban stormwater management by retaining rainwater that would otherwise will increase runoff and overflow the sewer system [4].

Energy consumption can be reduced by providing a layer of insulation around the building $[5,6]$. This keeps the building cooler hence reducing the reliance on air conditioning and also reducing the cooling load [7]. This layer of insulation also protects the building's from harmful ultra violet rays and other damaging weather conditions and as well as creating a sound barrier [8]. The environmental problem such as global warming, carbon footprints, urban heat island (UHI) and 
high energy consumption are the effects of urbanization. In order to overcome this problem, there must be an improved and sustainable technology could be implemented further to keep the environment stay balance with the urbanization. Thus, for this research, the green roof application on the energy reduction needs to be evaluated in order to support these assumptions. Therefore, the objectives for this research were:

1. to evaluate the efficiency of green roof technology in reducing roof temperature;

2. to investigate the performance of local plant species in reducing roof temperature;

3. to analyze the effect of substrate depth to the roof temperature.

\section{Materials and methods}

The experiment was conducted on two existing flat roofs belong to Malaysia Agricultural Research and Development (MARDI) Serdang, Selangor in Horticulture Research Centre, named as Roof 1 and Roof 2 . Roof 1 consist green roofs that planted with two species local vegetation named as Lantana camara (bunga tahi ayam) (LC) and Orthosiphon samineus (misai kucing) (OS) while Roof 2 is consists the same two species with additional species named as Portulaca grandifola (ros jepun) (PG). The treatments consist of two green roof system known as conventional system (CS) and self-watering system (SWS). The planter boxes have two different substrate depths which were $50 \mathrm{~mm}$ and $100 \mathrm{~mm}$. For this study, there were 16 plots of planter boxes on Roof 1 consist of two different species of vegetation, two different depths of substrate, two different techniques of planting system and their replication (Fig. 1); while 12 plots of planter boxes consists of three different species of vegetation with the same treatments of substrate depths, planting systems and replication (Fig. 2).

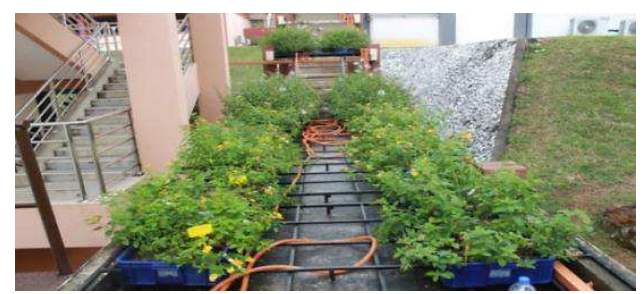

(a)

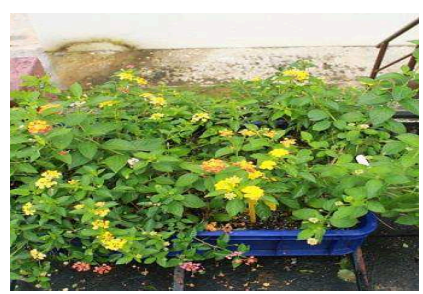

(b)

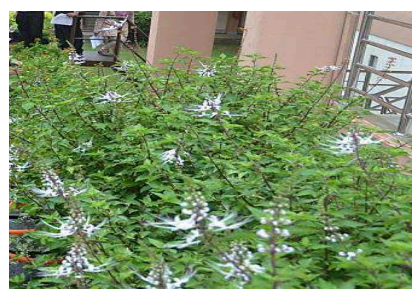

(c)

Fig. 1: (a) Roof 1 consists the existing green roofs planted with Lantana camara and Orthosiphon samineus; (b) Lantana camara species; and (c) Orthosiphon samineus species

The data observed were the temperatures on the top and bottom of the green roof boxes with the ambient temperature. Due to limited number of thermometer to measure all the 66 point at the same time, the observations were conducted in few cycles, which mean the thermometers, need to be shifted for every 15 minutes. Two thermometers were placed at both end of the green roof to collect the ambient temperature. The first cycle of the test was carried out by placing four thermometers under the planter box of Lantana camara and the rest of four thermometers under the planter box of Orthosiphon stamineus. Second cycle was carried out by shifting the thermometers on top of the green roof boxes of both species. The next cycles were performed alternately. Temperature data for Roof 1 was observed on $21^{\text {st }}$ November 2013 while for Roof 2 was on $25^{\text {th }}$ February 2014.

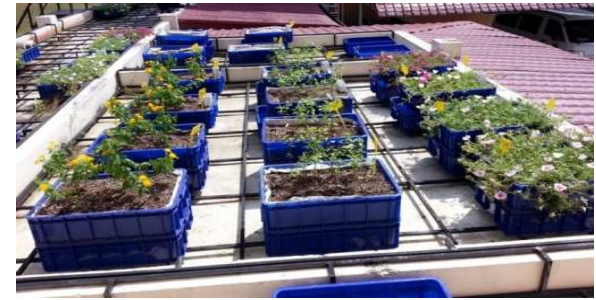

(a)

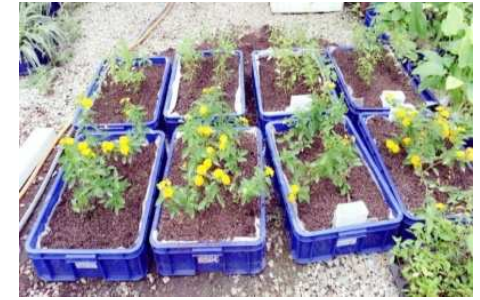

(b)

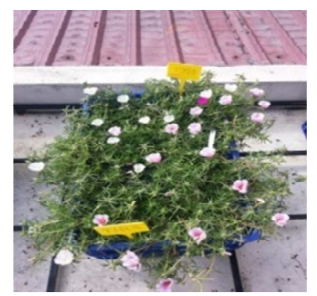

(c)

Fig. 2: (a) Roof 2 consists the new planted green roofs; from the left of the picture with Lantana camara, Orthosiphon samineus and Portulata grandiflora (b) Lantana camara species; and (c) 


\section{Results and Discussion}

Fig. 3 and Fig. 4 show the comparison for both Roof 1 and Roof 2 for different substrate depths and different plant species. In addition, results from both figures also comparing the temperature between top and bottom of the green roofs; with the bare roof surface temperature (without the green roofs) and the ambient (atmosphere) temperature. The ambient temperature for Roof 1 was observed for every 1 hour, while for Roof 2 the comparison was done with the maximum ambient observed on the $25^{\text {th }}$ February 2014. It is obviously shown in Fig. 3 and Fig. 4 that the roofs and the ambient temperatures without the green roofs were significantly higher. The average bare roof temperature increment for Roof 1 was $3.0^{\circ} \mathrm{C}$ from ambient temperature whilst for Roof 2 was almost $10^{\circ} \mathrm{C}$. The highest bare roof temperature increment was $3.3^{\circ} \mathrm{C}$ observed at 10.15 am for Roof 1 and $15^{\circ} \mathrm{C}$ for Roof 2 at $12.00 \mathrm{pm}$. While the lowest bare roof temperature increment that was $2.7^{\circ} \mathrm{C}$ occurs at $2.45 \mathrm{pm}$ on Roof 1 due to rain.

Due to the role of shades at the bottom of planter boxes, it is obviously seen that temperatures under the planter box on the afternoon between 10:00 pm to 3:00 pm were constantly low at less than $35^{\circ} \mathrm{C}$ for Roof 2 (Fig. 4). However, no constant reductions for the Roof 1 because the weather on $21^{\text {st }}$ November 2013 was changing throughout the days with shines, rainfall and winds hence the meteorological parameters were changed too, but the temperatures still maintained less than $31.4^{\circ} \mathrm{C}$. However, no meteorological parameters data were observed on that day. For the temperatures on top of the planter box, no constant reduction observed for Roof 1 as well, may due to the additional of high dense of vegetation foliage occurrence for Roof 1 have provided shades on top of the planter boxes too and it varied between $31.4^{\circ} \mathrm{C}$ and $27.0^{\circ} \mathrm{C}$. The temperatures for top location of Roof 2 were varied in high range may be due to the new planted green roofs, hence the dense foliage for this roofs were low and the substrates seem absorbed more heat where for highest temperature observed on that day was $50.3^{\circ} \mathrm{C}$ due to the high ambient temperature at $40.3^{\circ} \mathrm{C}$.

Fig 3(a) and Fig 3(b) show that there were slight difference temperatures recorded between two species, depths and planting system. Depth of substrate did not influence much of the temperature readings for the top soil if the leaves density is high as monitored in Roof 1.

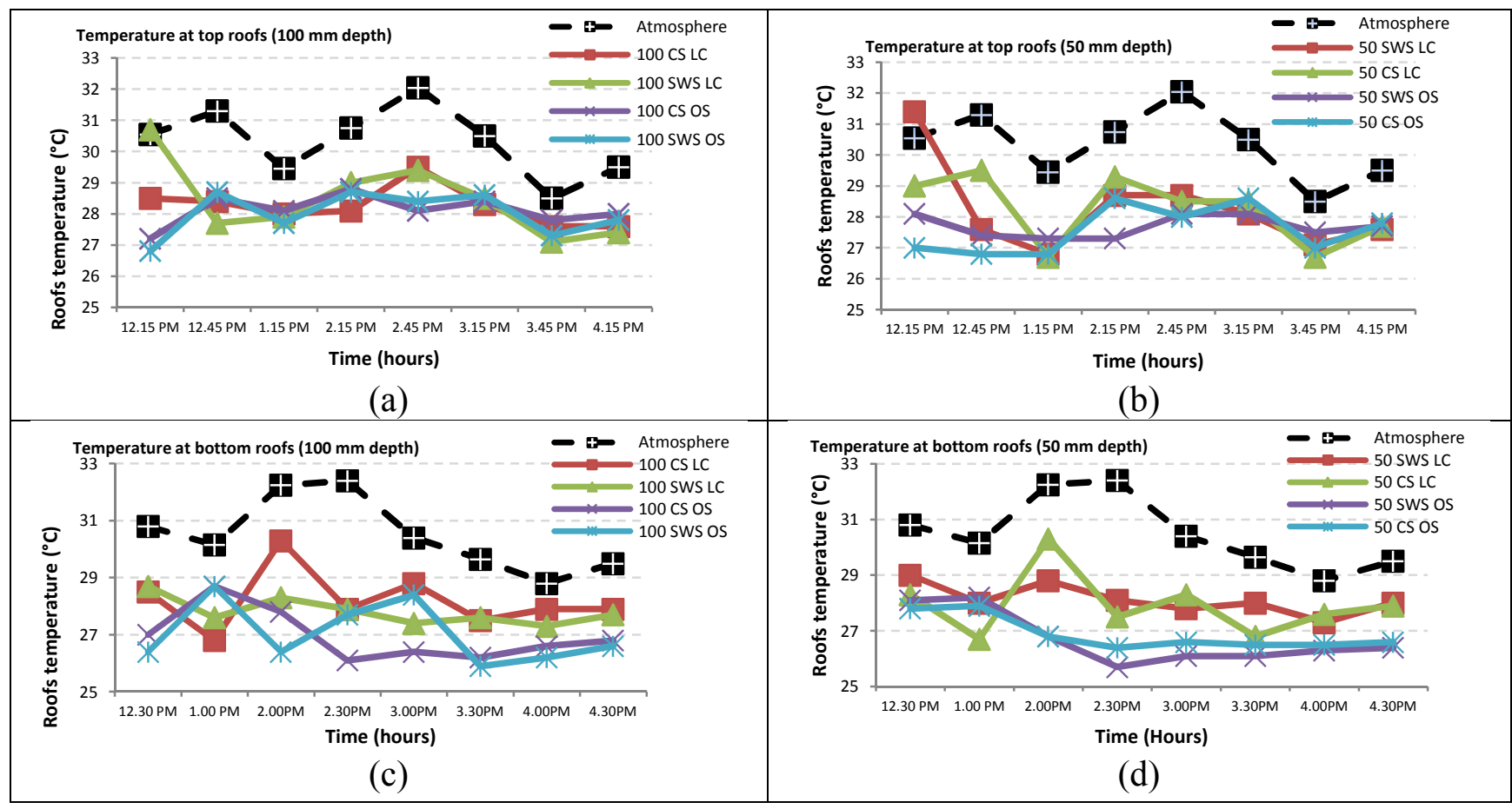

Fig 3: Green roofs temperature at Roof 1 with Lantana camara (LC) and Orthosiphon stamineus (OS) plots with respect to: (a) $100 \mathrm{~mm}$ depth - top roofs; (b) $50 \mathrm{~mm}$ depth - top roofs; (c) $100 \mathrm{~mm}$ depth - bottom roofs; (d) $50 \mathrm{~mm}$ - bottom roofs 
However for a deeper substrate with less density of vegetation, the soil had absorbed more heat and increased the temperature, as shown in Fig 4(a) and Fig 4(b) where low dense of Lantana camara in a deeper substrate had high temperature $50.3^{\circ} \mathrm{C}$ rather than the Lantana camara in $50 \mathrm{~mm}$ depth with $46.8^{\circ} \mathrm{C}$.

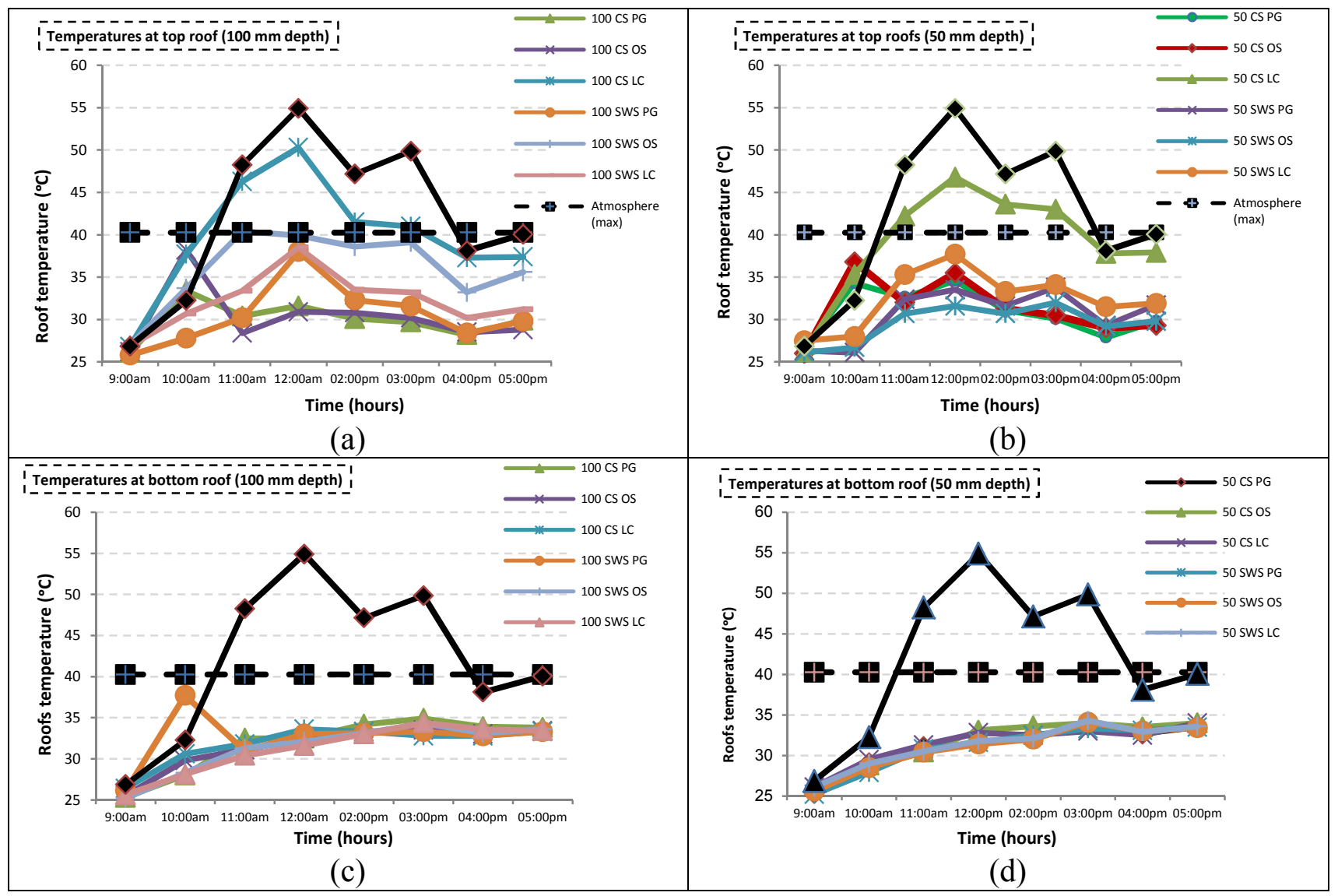

Fig 4: Green roofs temperature at Roof 2 with Lantana camara (LC), Orthosiphon stamineus (OS) and Portulaca grandiflora (GP) plots with respect to: (a) $100 \mathrm{~mm}$ depth - top roofs; (b) $50 \mathrm{~mm}$ depth - top roofs; (c) $100 \mathrm{~mm}$ depth - bottom roofs; (d) $50 \mathrm{~mm}$ - bottom roofs

Fig 5 and Fig 6 show the temperature relation between bare surface and green surfaces in 50 $\mathrm{mm}$ and $100 \mathrm{~mm}$ substrate's depth for low dense foliage in Roof 2. Initial overview shows that substrate's depth does not show any significant difference but in types of vegetation and planting system. Average substrates represent the temperature of bare soils (without vegetation) roof, selfwatering roof with all 3 types of vegetation and Lantana camara with conventional system roof show high correlation with bare surface roof. This could explain that due to high temperature occurrence, bare soils and self-watering system could absorbed more heat during high temperature where the correlation is linear at 1:1 for both substrate's depth. Green roof's temperatures also has good correlation with the bare roof but obviously has temperature range lower than $40.0^{\circ} \mathrm{C}$. While the range of fluctuation in the conventional system for Portulata grandiflora and Orthosiphon samineus types are much smaller than in bare roofs which vary between $26.0^{\circ} \mathrm{C}$ and $35.5^{\circ} \mathrm{C}$ for substrate of $50 \mathrm{~mm}$ depth and $26.1^{\circ} \mathrm{C}$ and $38.0^{\circ} \mathrm{C}$ for $100 \mathrm{~mm}$ substrate's depth which lower than the maximum ambient temperature which is at $40^{\circ} \mathrm{C}$ (maximum) on $25^{\text {th }}$ February 2014. 


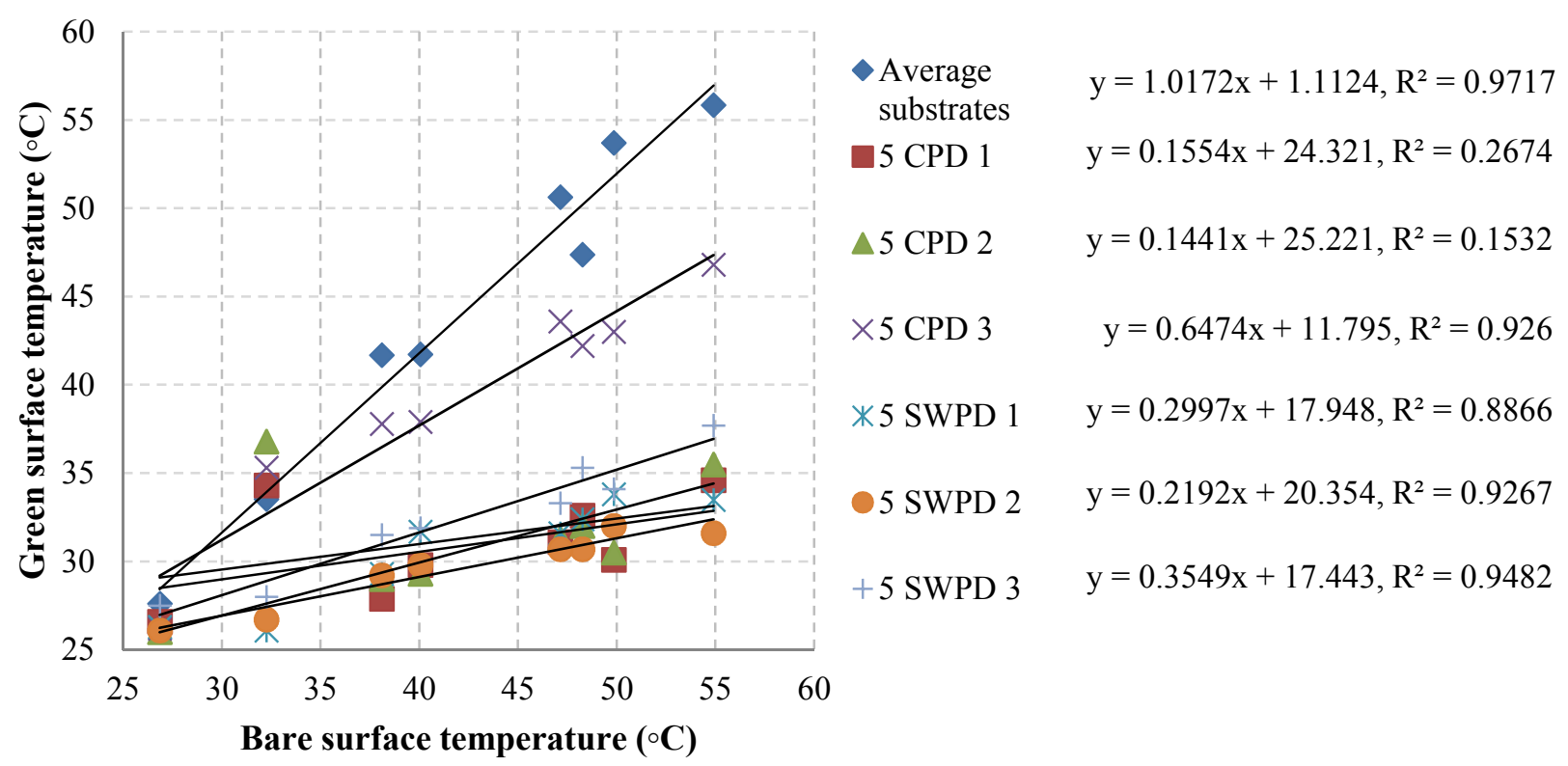

Fig 5: Comparison of green roof's surface temperature versus bare's surface temperature in $50 \mathrm{~mm}$ substrate's depth

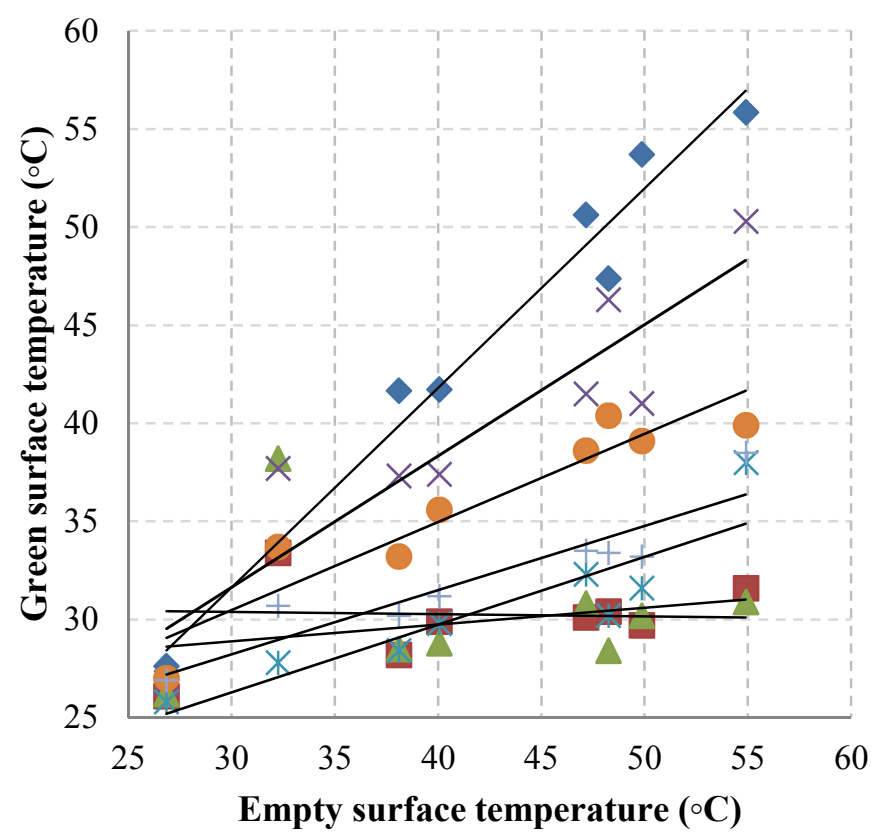

$$
\begin{aligned}
& \begin{array}{l}
\text { Average } \\
\text { substrates }
\end{array} \\
& \square 10 \text { CPD } 1 \quad \mathrm{y}=0.0856 \mathrm{x}+26.313, \mathrm{R}^{2}=0.1425 \\
& \triangle 10 \text { CPD } 2 \quad y=-0.0114 x+30.729, R^{2}=0.0009 \\
& \times 10 \text { CPD } 3 \quad y=0.669 x+11.573, R^{2}=0.8329 \\
& \text { *10 SWPD } 1 \quad \mathrm{y}=0.3452 \mathrm{x}+15.929, \mathrm{R}^{2}=0.7984 \\
& 10 \text { SWPD } 2 \quad y=0.4492 x+16.994, R^{2}=0.885 \\
& +10 \text { SWPD } 3 y=0.3265 x+18.429, R^{2}=0.8579
\end{aligned}
$$

Fig 6: Comparison of green roof's surface temperature versus bare's surface temperature in $100 \mathrm{~mm}$ substrate's depth

This study shows that the mature Orthosiphon samineus and Portulata grandiflora are able to reduce the roof temperature remarkably compare to Lantana camara due to its evergreen foliage and shadow effect. Both of them are flowering plants that have aesthetical value as well as medicinal properties. The MARDI's green roof promotes mix-culture system of the two flowering species plants. From the observation, the plants able to attracts various fauna to the ecosystem. The color and nectar of the flowers attract insects and birds into the ecosystem as shown in Fig 7. In addition, these insects and birds are also the agent of dispersal and pollination because they carry seeds from other places into this plot. Thus this flora-fauna interaction also allows the influx of other species and consequently increases in biodiversity [9]. 

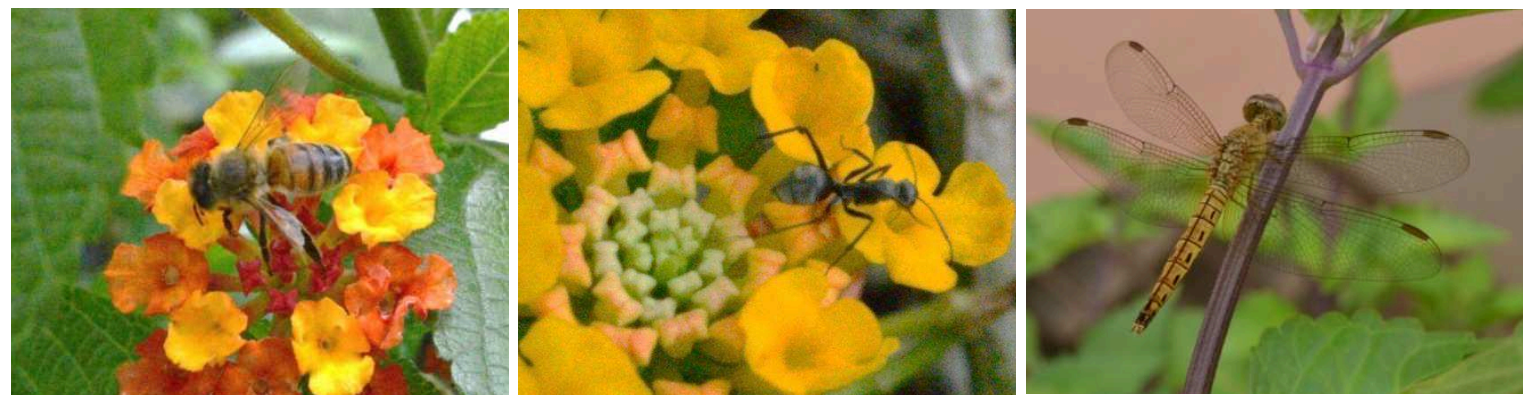

Fig 7: The presence of insects and birds such as Anisoptera, Apis mellifera and Camponotus pennsylvanicus will enhance the ecosystem

\section{Conclusions}

From the analytical results, the temperature reduction of MARDI green roofs on Roof 1 was recorded between $4.2^{\circ} \mathrm{C}$ and $10.0^{\circ} \mathrm{C}$ or in average $6.1^{\circ} \mathrm{C}$ during normal weather. On the other hand, the reduction for Roof 2 was between $7.0^{\circ} \mathrm{C}$ and $15.0^{\circ} \mathrm{C}$ or in average $10^{\circ} \mathrm{C}$ during extreme dry weather. The meteorological parameters were significantly influenced and it is suggested to be monitored in future study. In comparison, $O$. stamineus and $P$. grandiflora show better thermal performance compare to L. camara. It should be noted that the depth of substrate did not play a significant role in reducing the temperature. It is true if the planted vegetation did not achieved its maturity with high density leaves occurrences and provide shades for the green roof's substrate and reduce the heat absorption. This is shown by slight difference in temperature reduction between the two species planted in different substrate depths in Roof 1 and significant difference for three new planted vegetations in Roof 2.

\section{References}

[1] Livingroof.org (2014) Enviromental Advantages. European Federation of Green Roof Associations - EFB http://www.efb-greenroof.eu/verband/fachbei/fa01_englisch.html [Accessed March 25, 2014].

[2] Hui, S.C.M., (2011). Green Roof Urban Farming for Buildings in High-Density Urban Cities. World Green Roof Conference. 1-9.

[3] Environa Studio (2014). North Sydney Council Green Roof and Wall Resource Manual. http://www.northsydney.nsw.gov.au/files/64f81e6d-b69c-432c-8b35-a22e00de33d5/NSC Green Roof Resource Manual.pdf [Accessed March 25, 2014].

[4] Stovin, V.R., Vesuviano, G. \& Kasmin, H. (2012). The Hydrological Performance of a Green Roof Test Bed Under UK Climatic Conditions. Journal of Hydrology, 414-415, 148-161.

[5] EPA, United States Environmental Protection Agency (2014). Reducing Energy Use. http://www.epa.gov/greenhomes/ReduceEnergy.htm [Accessed March 25, 2014].

[6] Hoyano. A., (1999). Climatological Uses of Plants for Solar Control and the Effects on the Thermal Environment of a Building. Energy and Buildings, vol. 11, 181-99.

[7] Onmura, S., Matsumoto, M. and Hokoi, S, (2001). Study on Evaporative Cooling Effect of Roof Lawn Gardens. Energy and Buildings, 33(7), 653-666.

[8] Loh, S., (2009). Living Walls - A Way to Green The Built Environment. BEDP Environment Design Guide, 1(TEC 26), 1-7.

[9] Osman, N., Ali, F. H., \& Barakbah, S. S., (2009). The Role of Pioneer Vegetations in Accelerating the Process of Natural Succession. American Journal of Environmental Sciences, 5(1), 7-15. 